\title{
Effect of procalcitonin-guided antibiotic treatment on clinical outcomes in intensive care unit patients with infection and sepsis patients: a patient-level meta-analysis of randomized trials
}

Yannick Wirz ${ }^{1 \dagger}$, Marc A. Meier ${ }^{1 \dagger}$, Lila Bouadma ${ }^{3}$, Charles E. Luyt ${ }^{4}$, Michel Wolff ${ }^{3}$, Jean Chastre ${ }^{4}$, Florence Tubach ${ }^{5}$, Stefan Schroeder ${ }^{6}$, Vandack Nobre ${ }^{7}$, Djillali Annane ${ }^{8}$, Konrad Reinhart $^{9}$, Pierre Damas ${ }^{10}$, Maarten Nijsten ${ }^{11}$, Arezoo Shajiei ${ }^{11}$, Dylan W. deLange ${ }^{12}$, Rodrigo O. Deliberato ${ }^{13}$, Carolina F. Oliveira ${ }^{14}$, Yahya Shehabi ${ }^{15,16}$, Jos A. H. van Oers ${ }^{17}$, Albertus Beishuizen ${ }^{18}$, Armand R. J. Girbes ${ }^{19}$, Evelien de Jong ${ }^{19}$, Beat Mueller ${ }^{1,2}$ and Philipp Schuetz ${ }^{1,2^{*}}$

\begin{abstract}
Background: The clinical utility of serum procalcitonin levels in guiding antibiotic treatment decisions in patients with sepsis remains unclear. This patient-level meta-analysis based on 11 randomized trials investigates the impact of procalcitonin-guided antibiotic therapy on mortality in intensive care unit (ICU) patients with infection, both overall and stratified according to sepsis definition, severity, and type of infection.

Methods: For this meta-analysis focusing on procalcitonin-guided antibiotic management in critically ill patients with sepsis of any type, in February 2018 we updated the database of a previous individual patient data meta-analysis which was limited to patients with respiratory infections only. We used individual patient data from 11 trials that randomly assigned patients to receive antibiotics based on procalcitonin levels (the "procalcitonin-guided" group) or the current standard of care (the "controls"). The primary endpoint was mortality within 30 days. Secondary endpoints were duration of antibiotic treatment and length of stay.

Results: Mortality in the 2252 procalcitonin-guided patients was significantly lower compared with the 2230 control group patients ( $21.1 \%$ vs $23.7 \%$; adjusted odds ratio 0.89 , $95 \%$ confidence interval (CI) 0.8 to 0.99 ; $p=0.03$ ). These effects on mortality persisted in a subgroup of patients meeting the sepsis 3 definition and based on the severity of sepsis (assessed on the basis of the Sequential Organ Failure Assessment (SOFA) score, occurrence of septic shock or renal failure, and need for vasopressor or ventilatory support) and on the type of infection (respiratory, urinary tract, abdominal, skin, or central nervous system), with interaction for each analysis being $>0.05$. Procalcitonin guidance also facilitated earlier discontinuation of antibiotics, with a reduction in treatment duration (9.3 vs 10.4 days; adjusted coefficient -1.19 days, $95 \% \mathrm{Cl}-1.73$ to $-0.66 ; p<0.001)$.

(Continued on next page)
\end{abstract}

\footnotetext{
* Correspondence: schuetzph@gmail.com

†Yannick Wirz and Marc A. Meier contributed equally to this work.

${ }^{1}$ Medical University Department, Kantonsspital Aarau, Tellstrasse, $\mathrm{CH}-5001$ Aarau, Switzerland

${ }^{2}$ Faculty of Medicine, University of Basel, Basel, Switzerland

Full list of author information is available at the end of the article
}

(c) The Author(s). 2018 Open Access This article is distributed under the terms of the Creative Commons Attribution 4.0 International License (http://creativecommons.org/licenses/by/4.0/), which permits unrestricted use, distribution, and reproduction in any medium, provided you give appropriate credit to the original author(s) and the source, provide a link to the Creative Commons license, and indicate if changes were made. The Creative Commons Public Domain Dedication waiver (http://creativecommons.org/publicdomain/zero/1.0/) applies to the data made available in this article, unless otherwise stated. 
(Continued from previous page)

Conclusion: Procalcitonin-guided antibiotic treatment in ICU patients with infection and sepsis patients results in improved survival and lower antibiotic treatment duration.

Keywords: Sepsis, Procalcitonin, Antibiotic stewardship, Meta-analysis,

\section{Background}

Sepsis, defined as life-threatening organ dysfunction caused by a dysregulated host response to infection, remains a major healthcare problem worldwide and affects millions of people each year [1, 2]. Early identification and appropriate initial management including the start of antibiotic treatment and fluid resuscitation improves outcomes [2, 3]. In addition, monitoring of patients during treatment both for timely escalation of therapy in case of treatment failure and de-escalation in case of a favorable treatment response has an important impact on patient recovery. [1, 2] This also includes early de-escalation or cessation of antibiotic treatment once a patient's condition has stabilized, with signs indicating progression towards the resolution of infection.

Given that clinical signs for monitoring patients with sepsis can be ambiguous, the use of additional biomarkers mirroring specific physiopathological pathways has been proposed. In this context, serum procalcitonin (PCT) has emerged as a sensitive biomarker that provides prognostic information in patients with infections, and thus may improve sepsis management [4, 5]. Multiple studies have demonstrated that PCT levels increase in response to bacterial infection and decrease during recovery $[4,5]$. Reflecting the host response to a bacterial infection, PCT thus provides important adjunctive information in addition to traditional clinical and diagnostic parameters [6].

Multiple trials have investigated the benefits of using serum PCT levels to guide whether and for how long antibiotic therapy is used-a process referred to as PCT-guided antibiotic stewardship-in patients with infection in the intensive care unit (ICU) [1, 7-17]. While most trials have focused on the effects of PCT guidance on antibiotic usage, a recent large trial from the Netherlands reported lower mortality following PCT-guided therapy [10]. However, conclusive evidence on the safety of this approach across different types of infection and sepsis severities has been limited due to largely insufficient statistical power in most of the individual trials. Moreover, meta-analyses focusing on the impact of PCT-guided antibiotic stewardship in sepsis patients on clinical outcomes overall and within patient subgroups based on infection type and severity have been inconclusive [18, 19]. A noteworthy limitation of these meta-analyses was that they were based on aggregate data, limiting opportunities to harmonize outcome definitions among trials and to investigate the impact of PCT guidance in different patient subgroups.

To address this significant drawback of earlier meta-analyses, we performed a meta-analysis of individual patient data from 11 randomized-controlled trials (RCTs) to assess the safety of using PCT to guide antibiotic decisions in ICU patients with infection and different sepsis severities and with the involvement of different organs.

\section{Methods \\ Definition of patient population and trial selection}

For this meta-analysis focusing on PCT-guided antibiotic management in critically ill patients with sepsis, we updated the database of a previous individual patient data meta-analysis which was limited to patients with respiratory infections only $[20,21]$. Trial selection and data collection were performed following the initial protocol published in the Cochrane Library [22] and the report was prepared according to PRISMA individual participant data (IPD) guidelines [23, 24].

For this analysis, we included all patients residing in an ICU with any type of systemic infection. We thus excluded patients not treated in the ICU and also one trial that focused on ventilator-associated pneumonia because these patients may not have systemic bacterial infections [25]. Furthermore, pediatric trials and those not using PCT to guide initiation and duration of antibiotic treatment were excluded from this analysis.

Given that the definition of sepsis has changed over time [26], and is used differently among researchers and clinicians, we decided to focus primarily on trials involving patients presenting with infections to the critical care unit. However, we performed a subgroup analysis on patients meeting the sepsis 3 definition [26]. We also stratified the analysis based on sepsis severity and type of organ involved. Individual patient data were collected from eligible RCTs which assessed adults meeting these criteria.

\section{Trial search and data collection}

The search strategy for this review was updated in February 2018 in collaboration with personnel from the Cochrane collaboration and executed in all databases from the date of their inception to February 2018. All references were also screened for eligibility. Databases searched included the Cochrane Central Register of 
Controlled Trials (CENTRAL; January 2017, issue 1), MEDLINE Ovid (1966 to February 2017), and Embase.com (1980 to February 2017). We applied no language or publication restrictions.

Two authors (YW and MAM) independently assessed trial eligibility based on titles, abstracts, and full-text reports, with further information being obtained directly from investigators as needed. Study protocols, case report forms, and unedited databases containing individual patient data were requested from investigators of all eligible trials. Data from each trial were first checked against reported results and queries were resolved with the principal investigator, trial data manager, or statistician. Data were assessed in a consistent manner across all trials, with standard definitions and parameters, and thus mortality rates differed slightly from previous reports. In accordance with the Cochrane methodology, we used the Grading of Recommendations, Assessment, Development, and Evaluation (GRADE) approach to assess risk of selection bias, performance bias, detection bias, attrition bias, reporting bias, and other types of bias [27]. The grading was performed by two authors (YW and MAM) and, in case of conflicting results, grading was discussed with another author (PS) and within the meta-analysis group.

\section{Patients and endpoints}

All patients with a suspected or proven infection as the main diagnosis treated in the ICU who were included in a previous trial and randomized either to PCT-guided care or a control group were included in the overall analysis. The primary safety endpoint was all-cause mortality within 30 days of randomization. For trials with a shorter follow-up period, the available information was used (e.g., mortality at the time of hospital discharge). The main efficacy endpoint was antibiotic treatment duration. Other clinical endpoints included length of hospital stay and length of ICU stay.

\section{Statistical analysis}

The analysis follows a study protocol similar to a previous protocol published in the Cochrane Library [22] but we specified the main analysis and subgroup analysis for the sepsis patient population. For the primary endpoint (mortality), odds ratios (ORs) and 95\% confidence intervals (CIs) were calculated using multivariable hierarchical logistic regression [28, 29]. Variables in the multivariate analysis included treatment arm, age, gender, and type of infection. To control for within- and between-trial variability, a "trial" variable was added to the model as a random effect.

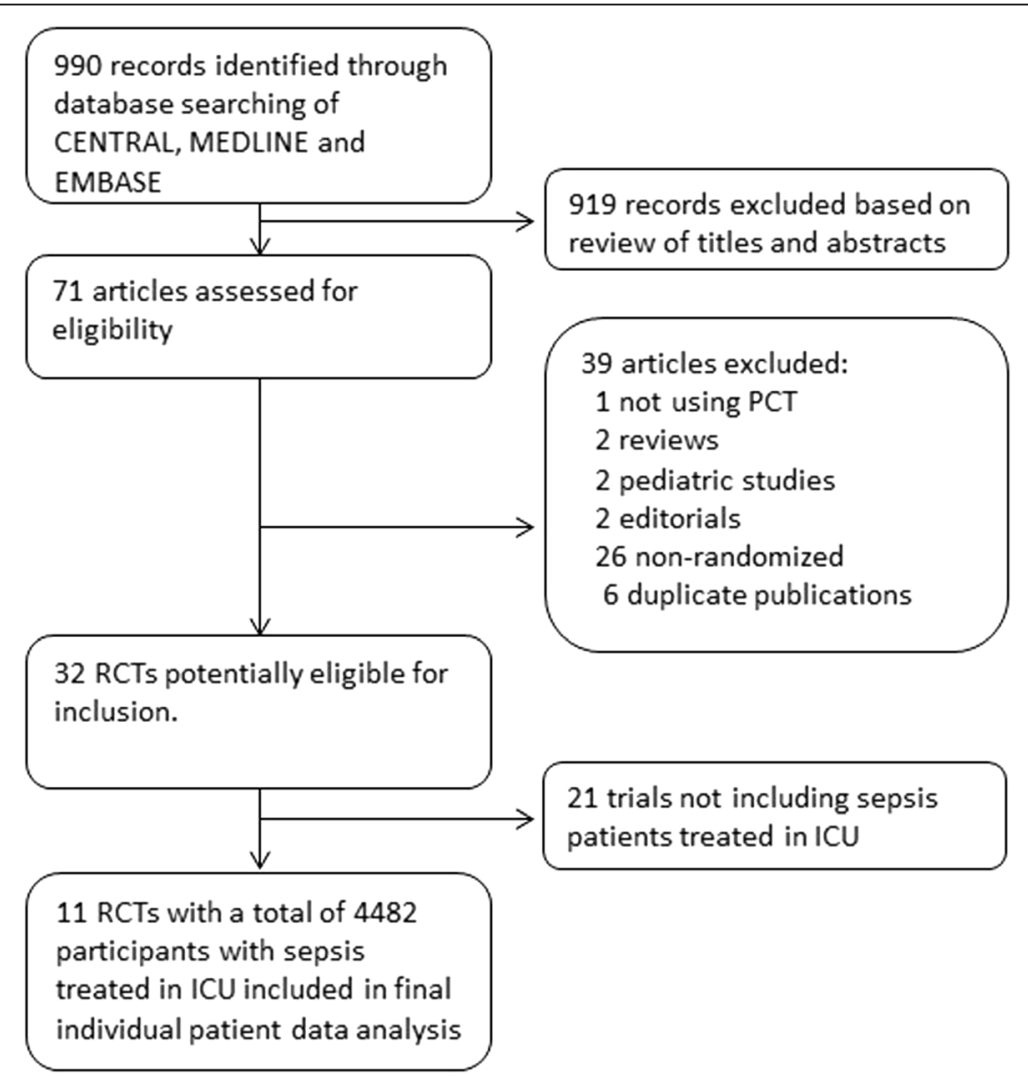

Fig. 1 Study flow diagram. ICU intensive care unit, PCT procalcitonin, RCT randomized controlled trial 
Corresponding linear and logistic regression models were fitted for continuous and binary secondary endpoints, respectively. Analyses followed the intention-to-treat principle by analyzing patients in groups to which they were randomized. Censoring was used for patients with a follow-up $<30$ days for the time-to-event analyses.

We performed a prespecified subgroup analysis on patients meeting the sepsis 3 definition, i.e., defining sepsis as life-threatening organ dysfunction due to a dysregulated host response to infection, and, as such, requires at least one organ dysfunction (i.e., at least one organ with a Sequential Organ Failure Assessment (SOFA) score above or equal to 2 [26]). Additional prespecified subgroup analyses were performed for sepsis severity (septic shock), treatment modality in the ICU, and type of organ infected. We tested for subgroup effects by adding interaction terms to the model. All statistical analyses were performed using Stata version 9.2 (College Station, Texas, USA) and Review Manager version 5.3.

\section{Results}

Results of the search and characteristics of included trials Data from 4482 individual patients enrolled in 11 of 32 potentially eligible trials were obtained and included in the meta-analysis (Fig. 1). A total of 21 trials whose patients did not have sepsis treated in the ICU and which thus did not meet our inclusion criteria were excluded. Included trials were conducted in seven countries including Switzerland, Germany, France, the Netherlands, Brazil, Belgium, and Australia (Table 1). There were two

Table 1 Characteristics of included trials

\begin{tabular}{|c|c|c|c|c|c|c|c|}
\hline $\begin{array}{l}\text { First } \\
\text { author } \\
\text { (year) }\end{array}$ & Country & $\begin{array}{l}\text { Setting, } \\
\text { type of } \\
\text { trial }\end{array}$ & $\begin{array}{l}\text { Patients } \\
\text { included }\end{array}$ & Follow-up & Clinical diagnosis & $\begin{array}{l}\text { Type of procalcitonin } \\
\text { algorithm; procalcitonin } \\
\text { cutoffs used }(\mu \mathrm{g} / \mathrm{L})^{\mathrm{a}}\end{array}$ & $\begin{array}{l}\text { Compliance } \\
\text { with the } \\
\text { PCT } \\
\text { protocol }\end{array}$ \\
\hline $\begin{array}{l}\text { Annane } \\
\text { (2013) [7] }\end{array}$ & France & $\begin{array}{l}\text { ICU, } \\
\text { multicenter }\end{array}$ & 62 & Hospital stay & $\begin{array}{l}\text { Severe sepsis without overt } \\
\text { source of infection and negative } \\
\text { blood culture }\end{array}$ & $\begin{array}{l}\text { Initiation and duration; } R \\
\text { against } A B:<0.5(<0.25) \text {; } R \\
\text { for } A B:>0.5(>5.0)\end{array}$ & $\begin{array}{l}63 \% \\
\text { adherence }\end{array}$ \\
\hline $\begin{array}{l}\text { Bloos } \\
(2016)[8]\end{array}$ & Germany & $\begin{array}{l}\text { ICU, } \\
\text { multicenter }\end{array}$ & 1089 & 3 months & $\begin{array}{l}\text { Severe sepsis or septic shock } \\
\text { (SIRS and documented infection } \\
+ \text { criteria for severe sepsis/septic } \\
\text { shock) }\end{array}$ & $\begin{array}{l}\text { Discontinuation at days } 4,7, \\
\text { and } 10 ; R \text { against } A B:<1.0 \\
\text { or }>50 \% \text { drop over previous } \\
\text { value }\end{array}$ & $\begin{array}{l}49.6 \% \\
\text { adherence }\end{array}$ \\
\hline $\begin{array}{l}\text { Bouadma } \\
(2010)[9]\end{array}$ & France & $\begin{array}{l}\text { ICU, } \\
\text { multicenter }\end{array}$ & 621 & 2 months & $\begin{array}{l}\text { Critically ill patients with } \\
\text { assumed/proven bacterial } \\
\text { infection }\end{array}$ & $\begin{array}{l}\text { Initiation and duration; } R \\
\text { against } A B:<0.5(<0.25) \text {; } R \\
\text { for } A B:>0.5(>1.0)\end{array}$ & $\begin{array}{l}47 \% \\
\text { adherence }\end{array}$ \\
\hline $\begin{array}{l}\text { De Jong } \\
(2016)[10]\end{array}$ & $\begin{array}{l}\text { The } \\
\text { Netherlands }\end{array}$ & $\begin{array}{l}\text { ICU, } \\
\text { multicenter }\end{array}$ & 1546 & 1 year & $\begin{array}{l}\text { Critically ill patients with } \\
\text { assumed infection }\end{array}$ & $\begin{array}{l}\text { Duration; } R \text { against } A B:<0.5 \\
\text { or }>80 \% \text { drop over peak } \\
\text { value }\end{array}$ & $\begin{array}{l}44 \% \\
\text { adherence }\end{array}$ \\
\hline $\begin{array}{l}\text { Deliberato } \\
\text { (2013) [11] }\end{array}$ & Brazil & $\begin{array}{l}\text { ICU, single } \\
\text { center }\end{array}$ & 81 & $\begin{array}{l}\text { ICU discharge or } \\
14 \text { days } \\
\text { postrandomization }\end{array}$ & $\begin{array}{l}\text { Sepsis patients with } \\
\text { microbiologically confirmed } \\
\text { bacterial infection }\end{array}$ & $\begin{array}{l}\text { Duration; } R \text { against } A B:<0.5 \\
\text { or }>90 \% \text { drop over peak } \\
\text { value }\end{array}$ & $\begin{array}{l}47.6 \% \\
\text { adherence }\end{array}$ \\
\hline $\begin{array}{l}\text { Hochreiter } \\
\text { (2009) [14] }\end{array}$ & Germany & $\begin{array}{l}\text { Surgical } \\
\text { ICU, single } \\
\text { center }\end{array}$ & 110 & Hospital stay & $\begin{array}{l}\text { Sepsis (SIRS and documented } \\
\text { infection) }\end{array}$ & $\begin{array}{l}\text { Duration; } R \text { against } A B:<1 \\
\text { or }>65 \% \text { drop over } 3 \text { days }\end{array}$ & $\begin{array}{l}\text { not } \\
\text { reported }\end{array}$ \\
\hline $\begin{array}{l}\text { Layios } \\
\text { (2012) [15] }\end{array}$ & Belgium & $\begin{array}{l}\mathrm{ICU} \text {, single } \\
\text { center }\end{array}$ & 379 & 1 month & $\begin{array}{l}\text { Critically ill patients with } \\
\text { assumed infection }\end{array}$ & $\begin{array}{l}\text { Initiation; } R \text { against } A B:<0.5 \\
(<0.25) ; R \text { for } A B:>0.5(>1.0)\end{array}$ & $\begin{array}{l}46.3 \% \\
\text { adherence }\end{array}$ \\
\hline $\begin{array}{l}\text { Nobre } \\
\text { (2008) [17] }\end{array}$ & Switzerland & $\begin{array}{l}\text { ICU, single } \\
\text { center }\end{array}$ & 79 & 1 month & Severe sepsis or septic shock & $\begin{array}{l}\text { Duration; } R \text { against } A B:<0.5 \\
(<0.25) \text { or }>80 \% \text { drop over } \\
\text { peak value; } R \text { for } A B:>0.5 \\
(>1.0)\end{array}$ & $\begin{array}{l}81 \% \\
\text { adherence }\end{array}$ \\
\hline $\begin{array}{l}\text { Oliveira } \\
\text { (2013) [16] }\end{array}$ & Brazil & $\begin{array}{l}\text { ICU, } \\
\text { multicenter }\end{array}$ & 94 & $\begin{array}{l}28 \text { days or } \\
\text { hospital discharge }\end{array}$ & $\begin{array}{l}\text { Severe sepsis or septic shock } \\
\text { (SOFA score > } 10 \text { and/or } \\
\text { bacteremia) }\end{array}$ & $\begin{array}{l}\text { Discontinuation; Initial < 1.0: } \\
\text { R against AB: } 0.1 \text { at day 4; } \\
\text { Initial > 1.0: } R \text { against: > 90\% } \\
\text { drop over peak value }\end{array}$ & $\begin{array}{l}87.8 \% \\
\text { adherence }\end{array}$ \\
\hline $\begin{array}{l}\text { Schroeder } \\
\text { (2009) [13] }\end{array}$ & Germany & $\begin{array}{l}\text { Surgical } \\
\text { ICU, single } \\
\text { center }\end{array}$ & 27 & Hospital stay & $\begin{array}{l}\text { Severe sepsis following } \\
\text { abdominal surgery (SIRS and } \\
\text { documented infection + criteria } \\
\text { for severe sepsis/septic shock) }\end{array}$ & $\begin{array}{l}\text { Duration; } R \text { against } A B:<1 \\
\text { or }>65 \% \text { drop over } 3 \text { days }\end{array}$ & $\begin{array}{l}\text { not } \\
\text { reported }\end{array}$ \\
\hline $\begin{array}{l}\text { Shehabi } \\
\text { (2014) [1] }\end{array}$ & Australia & $\begin{array}{l}\text { ICU, } \\
\text { multicenter }\end{array}$ & 394 & 3 months & $\begin{array}{l}\text { Sepsis (SIRS and documented } \\
\text { infection) }\end{array}$ & $\begin{array}{l}\text { Duration; } R \text { against } A B:<0.25 \\
(<0.1) \text { or }>90 \% \text { drop over } \\
\text { peak value }\end{array}$ & $\begin{array}{l}97 \% \\
\text { adherence }\end{array}$ \\
\hline
\end{tabular}

$A B$ antibiotic, ICU intensive care unit, PCT procalcitonin, $R$ recommendation, SIRS systemic inflammation response system, SOFA Sequential Organ Failure Assessment

${ }^{\text {a }}$ Cutoffs are listed as recommendation (strong recommendation) 
trials from surgical ICUs with postoperative sepsis patients, while the remaining nine trials focused on medical or mixed ICU patients with sepsis. All trials focused on sepsis patients but, as demonstrated in Table 1, definition of patients varied somewhat. The largest trials were those by De Jong $(n=1546)$ [10], Bloos $(n=1089)$ [8], and Bouadma $(n=621)$ [9]. The PCT algorithms used in the different trials were similar and mainly focused on early discontinuation of antibiotics if PCT dropped below $0.5 \mu \mathrm{g} / \mathrm{L}$ or by $80 \%$ from the peak level.

The quality of trials according to GRADE criteria was moderate to high (see Additional file 1). There was a low risk of selection bias, attrition bias, and reporting bias. Trials did not blind caregivers and patients with regard to the intervention and only about one-third of the trials featured blinded outcome assessment. There was no evidence of publication bias based on inspection of the funnel plot (see Additional file 1). We also found variable adherence to the PCT protocols ranging from $44 \%$ to $97 \%$ (Table 1).

Baseline characteristics of individual patients were similar between the PCT and control groups. About 50\% of patients had sepsis due to infection of the lung, followed by abdominal infection (18\%) and urinary tract infection (5\%). The mean SOFA score was 7.4 points and more than two-thirds of patients were on vasopressors and/or ventilation support. Table 2 lists additional baseline characteristics stratified according to randomization. There were no statistical differences between the two groups.

\section{Primary safety endpoint: mortality}

There were 529 deaths among 2230 control group patients (23.7\%) compared with 475 deaths among 2252 PCT-guided patients (21.1\%), resulting in significantly lower mortality in the PCT group (adjusted OR 0.89, 95\% CI 0.80 to $0.99 ; p=0.03$ ) (Fig. 2 and Table 3). This effect was consistent in patients meeting the sepsis 3 definition, and across different severity groups based on SOFA score, presence or absence of septic shock, ventilatory failure, and renal support $(p>0.05$ for each interaction, indicating no significant difference due to subgroup effect). The effects on mortality were also consistent among different types of infections including respiratory tract, urinary, abdominal, skin/soft tissue, and central nervous system (CNS) infections $(p>0.05$ for each interaction) (Table 4).

As an additional sensitivity analysis, a meta-analysis of the aggregate results of all trials was conducted (see Additional file 1). The point estimate for mortality in this analysis was similar to that seen in the individual patient data analysis but did not reach statistical significance (OR $0.88,95 \%$ CI 0.76 to 1.01 ). Heterogeneity was low, suggesting robust effects $\left(I^{2}=0 \%\right)$.
Table 2 Baseline characteristics of included patients

\begin{tabular}{|c|c|c|}
\hline Parameter & $\begin{array}{l}\text { Control group } \\
(n=2230)\end{array}$ & $\begin{array}{l}\text { PCT group } \\
(n=2252)\end{array}$ \\
\hline \multicolumn{3}{|l|}{ Demographics } \\
\hline Age (years) & $64.1 \pm 15.0$ & $63.5 \pm 15.2$ \\
\hline Male gender & $1281(57.5 \%)$ & $1273(56.5 \%)$ \\
\hline \multicolumn{3}{|l|}{ Primary focus of infection } \\
\hline Respiratory & 1101 (49.4\%) & $1102(48.9 \%)$ \\
\hline Urinary & $129(5.8 \%)$ & $118(5.2 \%)$ \\
\hline Abdominal & 417 (18.7\%) & $391(17.4 \%)$ \\
\hline Skin/soft tissue & $41(1.8 \%)$ & $32(1.4 \%)$ \\
\hline CNS & $35(1.6 \%)$ & $38(1.7 \%)$ \\
\hline Other/unknown & 440 (19.7\%) & $519(23.0 \%)$ \\
\hline Genital/gynecologic & $8(0.4 \%)$ & $3(0.1 \%)$ \\
\hline Catheter-related & $14(0.6 \%)$ & $16(0.7 \%)$ \\
\hline Bloodstream & $36(1.6 \%)$ & $25(1.1 \%)$ \\
\hline Upper respiratory & $9(0.4 \%)$ & $8(0.4 \%)$ \\
\hline \multicolumn{3}{|l|}{ Vital signs } \\
\hline Temperature $\left({ }^{\circ} \mathrm{C}\right)$ & $37.7 \pm 1.2$ & $37.8 \pm 1.1$ \\
\hline \multicolumn{3}{|l|}{ Sepsis score } \\
\hline Meeting sepsis 3 definition & $1630(73.1 \%)$ & $1605(71.3 \%)$ \\
\hline SOFA score (points) & $7.4 \pm 4.0$ & $7.3 \pm 4.1$ \\
\hline \multicolumn{3}{|l|}{ Additional sepsis support } \\
\hline Vasopressor use & $1593(76.3 \%)$ & $1606(76.7 \%)$ \\
\hline Ventilation support & $1434(68.1 \%)$ & 1478 (69.4\%) \\
\hline Renal replacement & 767 (34.4\%) & $757(33.6 \%)$ \\
\hline
\end{tabular}

As an additional sensitivity analysis, we restricted the analysis to trials reporting $\geq 28$ days mortality, thereby excluding three trials where this information was not assessed (Table 1). Again, results were similar to the main results.

\section{Primary efficacy endpoint: antibiotic use}

A moderate reduction in total antibiotic treatment duration resulted from PCT guidance (mean 10.4 \pm 9.7 vs $9.3 \pm 9.2$ days; adjusted regression coefficient -1.19 days, $95 \%$ CI -1.73 to $-0.66 ; p<0.001$ ) (Table 3). Effects were similar in patients meeting the sepsis 3 definition. There was some evidence of effect modification with stronger effects in patients with lower sepsis severity based on SOFA score ( -2.62 days in patients with SOFA score of 0-6 points vs 0.01 days in patients with SOFA score of 7-9 and -0.63 days in patients with SOFA scores of 10-24 ( $p$ for the interaction <0.05). Similarly, in patients with abdominal infection, PCT-guided therapy did not reduce duration of treatment compared with 


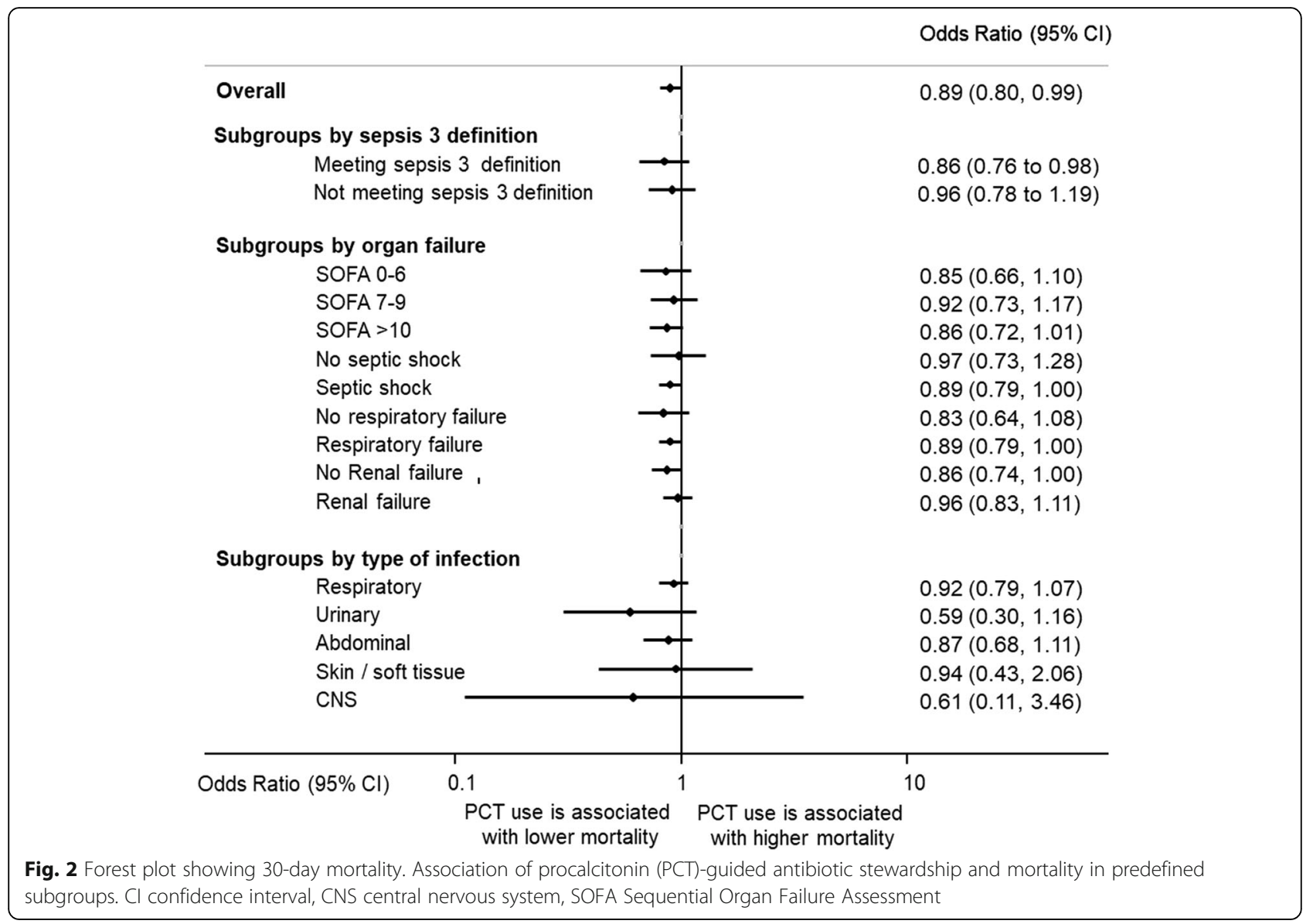

patients with all other infected organs, with the strongest effects being seen in patients with skin and soft tissue infections ( -4.6 days, $95 \%$ CI -10.36 to $1.23 ; p=0.122)$.

\section{Length of stay}

Length of hospital stay (adjusted regression coefficient 0.09 days, $95 \%$ CI -1.51 to $1.7 ; p=0.908$ ) and ICU stay (adjusted regression coefficient 0.04 days, $95 \%$ CI -0.9 to $0.99 ; p=0.928$ ) were similar in the PCT and control groups overall and in most subgroup analyses. Patients in the highest SOFA categories had longer lengths of ICU and hospital stay if PCT guidance had been used (3.21 days, 95\% CI -0.76 to 7.18 , and 2.08 days, $95 \%$ CI -0.08 to 4.24 , respectively). In addition, patients with renal failure (renal support) had longer lengths of hospital stay while patients with no renal failure had shorter stays (2.97 days vs -1.41 days).

\section{Discussion}

This meta-analysis of individual patient data from 11 randomized trials that included 4482 patients with infection treated in ICUs revealed lower mortality associated with PCT-guided therapy, confirming the results of a large Dutch trial [10]. This effect was consistent in sepsis patients based on the sepsis 3 definition, and across different severities and types of sepsis based on whether PCT-guided treatment was employed, and also across different types of infection. Moreover, PCT guidance was also associated with a modest reduction in exposure to antibiotics through shorter treatment durations and earlier discontinuation. However, PCT guidance did not have an effect on length of ICU or hospital stay.

Early diagnosis combined with initiation of appropriate antibiotic treatment remains the cornerstone of sepsis care [30]. Once treatment is initiated, close monitoring of patients is of the utmost importance to identify patients with a favorable disease course who are at low risk for complications so that one may consider early cessation of antibiotic therapy. Daily assessment of patient risk using objective prognostic parameters is therefore important. In addition to clinical parameters, blood markers may aid in patient monitoring [31-34]. While serum lactate is a commonly used biomarker that may help guide resuscitation measures [35], PCT has been previously demonstrated to be helpful in assessing the response to antimicrobial treatment and in aiding 
Table 3 Clinical endpoints overall and stratified by sepsis severity and use of sepsis support

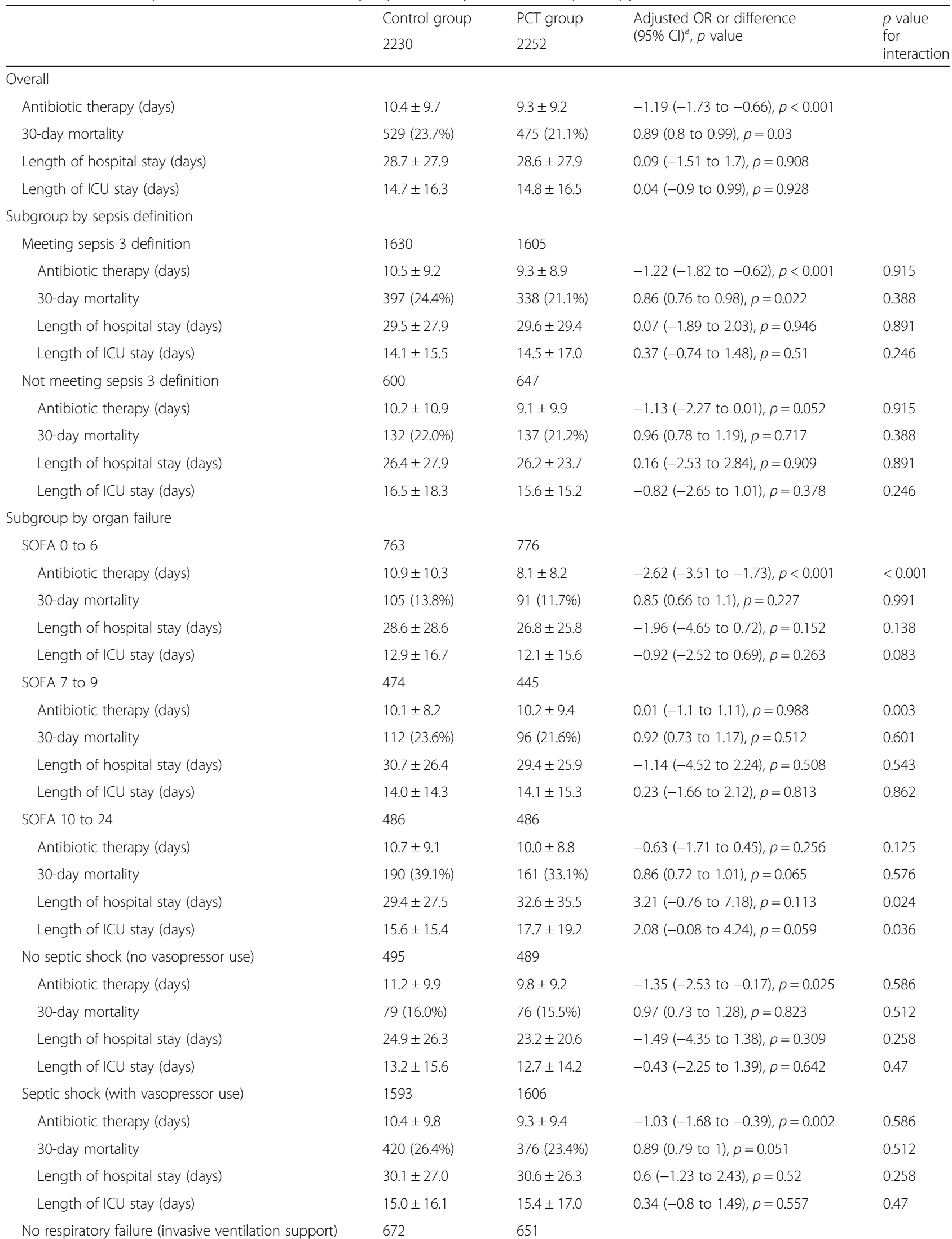


Table 3 Clinical endpoints overall and stratified by sepsis severity and use of sepsis support (Continued)

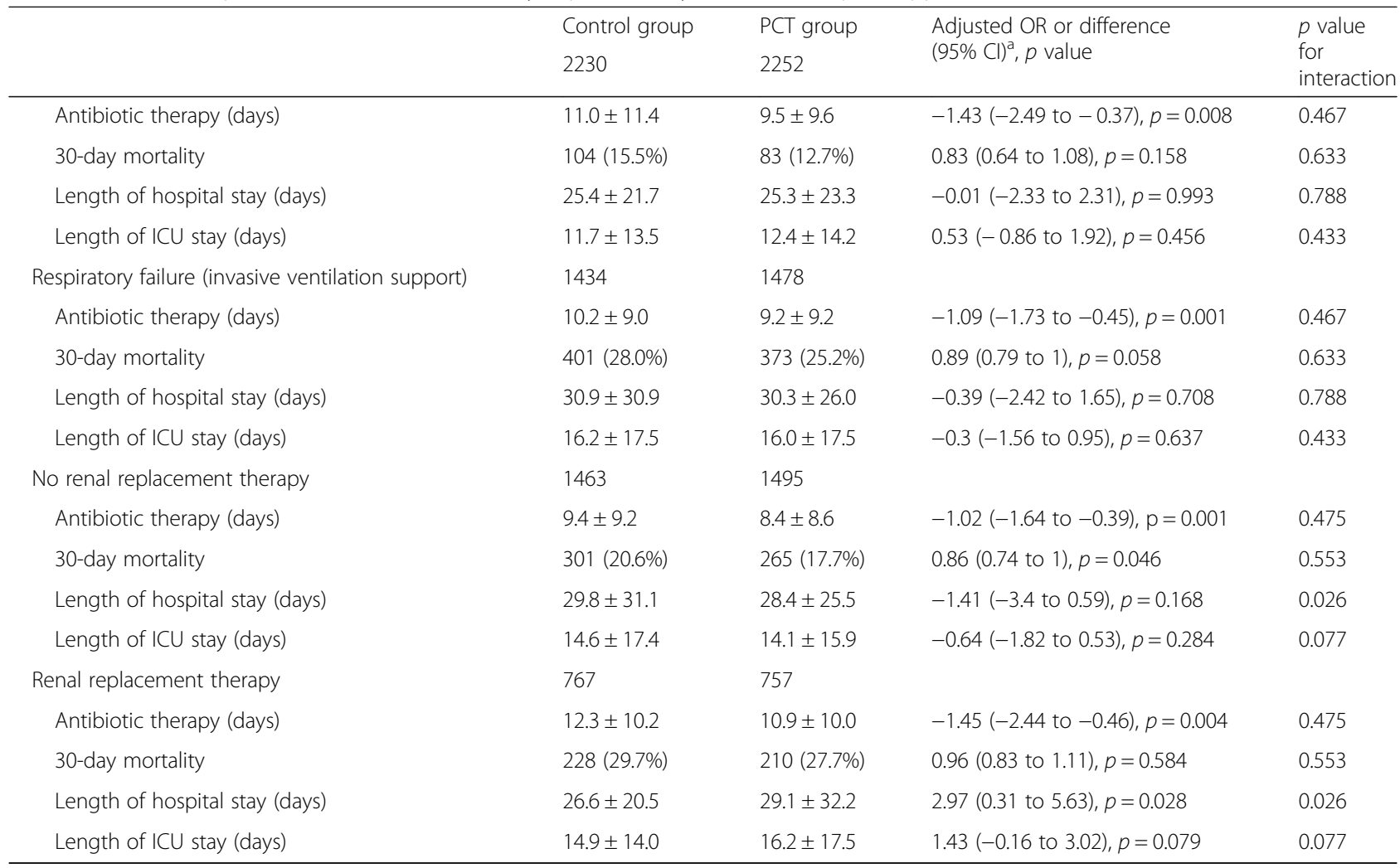

Values are presented as mean \pm standard deviation or $n(\%)$ as appropriate

$\mathrm{Cl}$ confidence interval, ICU intensive care unit, OR odds ratio, PCT procalcitonin, SOFA Sequential Organ Failure Assessment

${ }^{a}$ Multivariable hierarchical regression with outcome of interest as dependent variable and trial as a random effect

antibiotic stewardship decisions [36-38]. Based on multiple randomized trials integrated in an aggregate patient data meta-analysis, the US Food and Drug Administration (FDA) has recently approved the PCT assay for the purpose of guiding antibiotic therapy in the context of sepsis $[18,39]$. However, since sepsis is not a well-defined disease but a heterogenous syndrome arising from different possible organs being infected and with different clinical presentations based on severity, the question of safety and efficacy of PCT guidance in patients with sepsis overall, and in subgroups based on severity and organs involved, is relevant. In this context, our finding that lower mortality and shorter antibiotic courses are associated with PCT-guided care is reassuring.

We have recently published a similar individual patient data meta-analysis looking at patients with different types and severities of respiratory infections [20, 40]. Similar to what was seen in the current analysis, patients with respiratory infections also benefited from PCT-guided therapy, experiencing lower mortality and needing significantly reduced antibiotic exposure. The current analysis further expands these findings, also showing similar effects in subgroups of other types of infections-an analysis that was not possible in all previous meta-analyses based on aggregate data. While the effects seem similar between different subgroups, we did not find PCT to be associated with reduced antibiotic use in patients with abdominal infections and those with renal impairment. It is possible that, in these two patient groups, the PCT kinetics are impaired by bacterial translocation due to mucositis even if the initial infection has resolved, and by the slower decline of PCT in patients with renal impairment. Additional investigations will be needed to understand whether PCT algorithms require further adaptation in these two patient groups.

Although we have no definitive explanations for the positive effects of PCT-guided antibiotic treatment on mortality, several mechanisms seem plausible. First, PCT provides additional prognostic information in patients with sepsis and may influence site-of-care decisions and timing of discharge [17]. The MOSES study investigating PCT kinetics over $72 \mathrm{~h}$ in several US emergency departments validated the prognostic potential of PCT independent of other prognostic scores [4]. Hence, early identification of treatment nonresponders has the potential to prevent adverse events, although this was not true in the PASS trial, a study investigating whether escalation of diagnostic 
Table 4 Clinical endpoints stratified by type of infection

\begin{tabular}{|c|c|c|c|c|}
\hline & Control group & PCT group & Adjusted OR or difference $(95 \% \mathrm{Cl})^{\mathrm{a}}, p$ value & $p$ value for interaction \\
\hline \multicolumn{5}{|c|}{ Subgroup by type of infection (suspected infection site) } \\
\hline Respiratory & 1101 & 1102 & & \\
\hline Antibiotic therapy (days) & $9.9 \pm 7.8$ & $8.5 \pm 7.8$ & $-1.36(-1.99$ to -0.73$), p<0.001$ & 0.582 \\
\hline 30-day mortality & $262(23.8 \%)$ & $243(22.1 \%)$ & $0.92(0.79$ to 1.07$), p=0.299$ & 0.466 \\
\hline Length of hospital stay (days) & $28.2 \pm 27.7$ & $27.7 \pm 24.7$ & $-0.21(-2.36$ to 1.94$), p=0.849$ & 0.668 \\
\hline Length of ICU stay (days) & $15.1 \pm 16.6$ & $15.3 \pm 17.5$ & $0.19(-1.24$ to 1.61$), p=0.798$ & 0.858 \\
\hline Urinary & 129 & 118 & & \\
\hline Antibiotic therapy (days) & $12.5 \pm 12.4$ & $11.0 \pm 12.2$ & $-1.62(-4.6$ to 1.36$), p=0.286$ & 0.786 \\
\hline 30-day mortality & $21(16.3 \%)$ & $11(9.3 \%)$ & 0.59 (0.3 to 1.16$), p=0.128$ & 0.215 \\
\hline Length of hospital stay (days) & $29.5 \pm 25.4$ & $25.1 \pm 21.7$ & $-4.08(-9.7$ to 1.54$), p=0.154$ & 0.209 \\
\hline Length of ICU stay (days) & $14.3 \pm 20.5$ & $11.2 \pm 13.6$ & $-2.49(-6.68$ to 1.7$), p=0.244$ & 0.123 \\
\hline Abdominal & 417 & 391 & & \\
\hline Antibiotic therapy (days) & $10.5 \pm 10.6$ & $11.0 \pm 11.9$ & $0.55(-0.96$ to 2.06$), p=0.477$ & 0.005 \\
\hline 30-day mortality & $109(26.1 \%)$ & 89 (22.8\%) & $0.87(0.68$ to 1.11$), p=0.266$ & 0.821 \\
\hline Length of hospital stay (days) & $30.5 \pm 27.7$ & $32.1 \pm 27.8$ & $1.62(-2.18$ to 5.41$), p=0.404$ & 0.361 \\
\hline Length of ICU stay (days) & $15.1 \pm 15.3$ & $15.7 \pm 16.4$ & $0.42(-1.76$ to 2.6$), p=0.704$ & 0.634 \\
\hline Skin/soft tissue & 41 & 32 & & \\
\hline Antibiotic therapy (days) & $12.9 \pm 15.8$ & $8.6 \pm 8.5$ & $-4.57(-10.36$ to 1.23$), p=0.122$ & 0.159 \\
\hline 30-day mortality & $11(27 \%)$ & $8(25 \%)$ & 0.94 (0.43 to 2.06 ), $p=0.874$ & 0.918 \\
\hline Length of hospital stay (days) & $26.0 \pm 25.8$ & $20.9 \pm 23.4$ & $-4.17(-15.4$ to 7.06$), p=0.467$ & 0.442 \\
\hline Length of ICU stay (days) & $10.4 \pm 9.4$ & $10.9 \pm 12.7$ & $0.83(-4.18$ to 5.84$), p=0.747$ & 0.916 \\
\hline Central nervous system & 35 & 38 & & \\
\hline Antibiotic therapy (days) & $11.7 \pm 7.7$ & $10.4 \pm 7.7$ & $-1.7(-5.04$ to 1.63$), p=0.317$ & 0.958 \\
\hline 30-day mortality & $3(9 \%)$ & $2(5 \%)$ & 0.61 (0.11 to 3.46$), p=0.58$ & 0.692 \\
\hline Length of hospital stay (days) & $31.3 \pm 22.8$ & $30.8 \pm 25.7$ & $-0.44(-11.48$ to 10.6$), p=0.938$ & 0.954 \\
\hline Length of ICU stay (days) & $10.8 \pm 14.0$ & $13.7 \pm 13.1$ & $2.91(-3.22$ to 9.04$), p=0.352$ & 0.457 \\
\hline
\end{tabular}

Values are presented as mean \pm standard deviation or $n(\%)$ as appropriate

$\mathrm{Cl}$ confidence interval, ICU intensive care unit, OR odds ratio, $P C T$ procalcitonin

${ }^{a}$ Multivariable hierarchical regression with outcome of interest as dependent variable and trial as a random effect

and therapeutic measures based on high PCT levels would decrease mortality [41]. Second, prolonged antibiotic exposure has a toxic effect and thus may increase risk of treatment failure in control patients $[42,43]$. Unexpected PCT results may also prompt physicians to further examine patients and look for additional explanations and illnesses. Finally, several observational studies have reported lower mortality and risk of treatment failure associated with early antibiotic de-escalation in patients with sepsis, although pathophysiological mechanisms are incompletely understood [37, 44].

This analysis is based on a comprehensive literature search and retrieval of all relevant trials and a network that permitted inclusion of individual patient data from most eligible trials. We also standardized definitions across trials and were able to perform appropriate subgroup analyses looking at different sepsis severities and types of infection. Limitations of this analysis include incomplete adherence to the PCT algorithm among the included trials, exclusion of immunocompromised patients in most trials, and heterogeneity among trials with regard to patient populations and follow-up of patients. In addition, cost-effectiveness analyses need to be undertaken to determine whether using PCT-guided care is a cost-effective intervention [45].

\section{Conclusion}

In conclusion, PCT-guided antibiotic treatment in ICU patients with infection results in improved survival and shorter antibiotic treatment duration. Effects were similar in sepsis patients and among subgroups based on sepsis severity, sepsis treatment modalities, and type of infection. Whether the reduction in antibiotic exposure fully explains the mortality effects seen in our data needs 
to be investigated in future trials. These findings have substantial clinical and public health implications.

\section{Additional file}

Additional file 1: Figure S1. Assessment of risk of bias in included trials. Figure S2. Forrest plot based on aggregate data. Figure S3.

Funnel plots regarding possible publication bias. (PDF $57 \mathrm{~kb}$ )

\section{Acknowledgements}

We thank all patients involved in the individual trials and the investigators for sharing their data. Assistance with the preparation of the manuscript was provided by Prasad Kulkarni, PhD, CMPP of Asclepius Medical Communications LLC, Ridgewood, NJ, USA and was funded by BioMérieux Inc

\section{Funding}

This work was made possible by an unrestricted research grant from BioMérieux Inc.

\section{Availability of data and materials}

Data of the individual trials are available upon reasonable request based on the authorization of principal investigators of the trials.

\section{Authors' contributions \\ PS, YW, and MAM performed the literature search and all analyses included in this report and wrote the first draft. All authors shared trial data, gave critical feedback on the manuscript, and approved the final version for submission. PS had full access to all of the data in the study and takes responsibility for the integrity of the data and the accuracy of the data analysis. PS and BM oversaw the study and act as guarantors.}

\section{Ethics approval and consent to participate}

All trial included in the meta-analysis enrolled patients providing informed consent and had approval from their institutional review boards.

\section{Consent for publication}

Not applicable.

\section{Competing interests}

BioMérieux Inc. provided an unrestricted research grant to conduct this analysis. However, no personnel from the company were involved in the conduct of the analysis or in the preparation of the manuscript. PS and BM have received support from Thermo-Fisher and BioMérieux to attend meetings and fulfill speaking engagements. BM has also served as a consultant to BioMérieux and Thermo-Fisher. SS has received lecture fees and research support from Thermo-Fisher. CEL has received lecture fees from Brahms and Merck Sharp \& Dohme-Chibret. JC has received consulting and lecture fees from Pfizer, Brahms, Wyeth, Johnson \& Johnson, Nektar-Bayer, and Arpida. MW has received consulting and lectures fees from Merck Sharp \& DohmeChibret, Janssen-Cilag, Gilead, Astellas, Sanofi, and Thermo-Fisher. YS has received unrestricted research grants from Thermo-fisher, BioMérieux, Orion Pharma, and Pfizer. The remaining authors declare that they have no competing interests.

\section{Publisher's Note}

Springer Nature remains neutral with regard to jurisdictional claims in published maps and institutional affiliations.

\section{Author details}

${ }^{1}$ Medical University Department, Kantonsspital Aarau, Tellstrasse, $\mathrm{CH}-5001$ Aarau, Switzerland. 'Faculty of Medicine, University of Basel, Basel, Switzerland. ${ }^{3}$ Service de Réanimation Médicale, Université Paris 7-Denis-Diderot, AP-HP, Paris, France. ${ }^{4}$ Service de Réanimation Médicale, Université Paris 6-Pierre-et-Marie-Curie, Paris, France. ${ }^{5}$ Département d'Epidémiologie Biostatistique et Recherche Clinique, AP-HP, Hôpitaux Universitaires Paris Nord Val de Seine, Paris, France. ${ }^{6}$ Department of Anesthesiology and Intensive Care Medicine, Krankenhaus Dueren, Dueren,
Germany. ${ }^{7}$ Department of Intensive Care, Hospital das Clinicas da Universidade Federal de Minas Gerais, Belo Horizonte, Brazil. ${ }^{8}$ Critical Care Department, Hôpital Raymond Poincaré, Assistance Publique - Hôpitaux de Paris, Garches, France. ${ }^{9}$ Department of Anesthesiology and Intensive Care Medicine, Jena University Hospital, Jena, Germany. ${ }^{10}$ Department of General Intensive Care, University Hospital of Liege, Domaine universitaire de Liège, Liege, Belgium. " ${ }^{1}$ University Medical Centre, University of Groningen, Groningen, The Netherlands. ${ }^{12}$ University Medical Center Utrecht, Utrecht, The Netherlands. ${ }^{13}$ Laboratory for Critical Care Research, Critical Care Unit, Hospital Israelita Albert Einstein, São Paulo, Brazil. ${ }^{14}$ Department of Internal Medicine, School of Medicine, Universidade Federal de Minas Gerais, Belo Horizonte, Brazil. ${ }^{15} \mathrm{Critical}$ Care and Peri-operative Medicine, Monash Health, Melbourne, Australia. ${ }^{16}$ Faculty of Medicine Nursing and Health Sciences, School of Clinical Sciences, Monash University, Melbourne, Australia.

${ }^{17}$ Elisabeth Tweesteden Hospital, Tilburg, The Netherlands. ${ }^{18}$ Medisch Spectrum Twente, Enschede, The Netherlands. ${ }^{19} \mathrm{VU}$ University Medical Centre, Amsterdam, The Netherlands.

Received: 2 June 2018 Accepted: 10 July 2018

Published online: 15 August 2018

\section{References}

1. Shehabi Y, Sterba M, Garrett PM, Rachakonda KS, Stephens D, Harrigan P, Walker A, Bailey MJ, Johnson B, Millis D, et al. Procalcitonin algorithm in critically ill adults with undifferentiated infection or suspected sepsis. A randomized controlled trial. Am J Respir Crit Care Med. 2014;190(10): 1102-10.

2. Rhodes A, Evans LE, Alhazzani W, Levy MM, Antonelli M, Ferrer R, Kumar A, Sevransky JE, Sprung CL, Nunnally ME, et al. Surviving Sepsis Campaign: international guidelines for management of sepsis and septic shock: 2016 . Intensive Care Med. 2017:43(3):304-77.

3. Kumar A, Ellis P, Arabi Y, Roberts D, Light B, Parrillo JE, Dodek P, Wood G, Kumar A, Simon D, et al. Initiation of inappropriate antimicrobial therapy results in a fivefold reduction of survival in human septic shock. Chest. 2009; 136(5):1237-48.

4. Schuetz P, Birkhahn R, Sherwin R, Jones AE, Singer A, Kline JA, Runyon MS, Self WH, Courtney DM, Nowak RM, et al. Serial procalcitonin predicts mortality in severe sepsis patients: results from the multicenter procalcitonin MOnitoring SEpsis (MOSES) study. Crit Care Med. 2017:45(5):781-9.

5. Wacker C, Prkno A, Brunkhorst FM, Schlattmann P. Procalcitonin as a diagnostic marker for sepsis: a systematic review and meta-analysis. Lancet Infect Dis. 2013;13(5):426-35.

6. Mitsuma SF, Mansour MK, Dekker JP, Kim J, Rahman MZ, Tweed-Kent A, Schuetz P. Promising new assays and technologies for the diagnosis and management of infectious diseases. Clin Infect Dis. 2013;56(7):996-1002.

7. Annane D, Maxime V, Faller JP, Mezher C, Clec'h C, Martel P, Gonzales H, Feissel M, Cohen Y, Capellier G, et al. Procalcitonin levels to guide antibiotic therapy in adults with non-microbiologically proven apparent severe sepsis: a randomised controlled trial. BMJ Open. 2013;3(2):112-15.

8. Bloos F, Trips E, Nierhaus A, Briegel J, Heyland DK, Jaschinski U, Moerer O, Weyland A, Marx G, Grundling M, et al. Effect of sodium selenite administration and procalcitonin-guided therapy on mortality in patients with severe sepsis or septic shock: a randomized clinical trial. JAMA Intern Med. 2016;176(9):1266-76.

9. Bouadma L, Luyt CE, Tubach F, Cracco C, Alvarez A, Schwebel C, Schortgen $F$, Lasocki $S$, Veber B, Dehoux $M$, et al. Use of procalcitonin to reduce patients' exposure to antibiotics in intensive care units (PRORATA trial): a multicentre randomised controlled trial. Lancet. 2010;375(9713):463-74.

10. de Jong E, van Oers JA, Beishuizen A, Vos P, Vermeijden WJ, Haas LE, Loef BG, Dormans T, van Melsen GC, Kluiters YC, et al. Efficacy and safety of procalcitonin guidance in reducing the duration of antibiotic treatment in critically ill patients: a randomised, controlled, open-label trial. Lancet Infect Dis. 2016;16(7):819-27.

11. Deliberato RO, Marra AR, Sanches PR, Martino MD, Ferreira CE, Pasternak J, Paes AT, Pinto LM, dos Santos OF, Edmond MB. Clinical and economic impact of procalcitonin to shorten antimicrobial therapy in septic patients with proven bacterial infection in an intensive care setting. Diagn Microbiol Infect Dis. 2013;76(3):266-71.

12. Hochreiter M, Schroeder S. Procalcitonin-based algorithm. Management of antibiotic therapy in critically ill patients. Anaesthesist. 2011;60(7):661-73. 
13. Schroeder S, Hochreiter M, Koehler T, Schweiger AM, Bein B, Keck FS, von Spiegel T. Procalcitonin (PCT)-guided algorithm reduces length of antibiotic treatment in surgical intensive care patients with severe sepsis: results of a prospective randomized study. Langenbecks Arch Surg. 2009;394(2):221-6.

14. Hochreiter M, Kohler T, Schweiger AM, Keck FS, Bein B, von Spiegel T, Schroeder S. Procalcitonin to guide duration of antibiotic therapy in intensive care patients: a randomized prospective controlled trial. Crit Care. 2009;13(3):R83.

15. Layios N, Lambermont B, Canivet JL, Morimont P, Preiser JC, Garweg C, Ledoux D, Frippiat F, Piret S, Giot JB, et al. Procalcitonin usefulness for the initiation of antibiotic treatment in intensive care unit patients. Crit Care Med. 2012;40(8):2304-9.

16. Oliveira CF, Botoni FA, Oliveira CR, Silva CB, Pereira HA, Serufo JC, Nobre V. Procalcitonin versus $C$-reactive protein for guiding antibiotic therapy in sepsis: a randomized trial. Crit Care Med. 2013:41(10):2336-43.

17. Nobre V, Harbarth S, Graf JD, Rohner P, Pugin J. Use of procalcitonin to shorten antibiotic treatment duration in septic patients: a randomized trial. Am J Respir Crit Care Med. 2008;177(5):498-505.

18. lankova I, Thompson-Leduc P, Kirson NY, Rice B, Hey J, Krause A, Schonfeld SA, DeBrase CR, Bozzette S, Schuetz P. Efficacy and safety of procalcitonin guidance in patients with suspected or confirmed sepsis: a systematic review and meta-analysis. Crit Care Med. 2018;46(5):691-8.

19. Andriolo BN, Andriolo RB, Salomao R, Atallah AN. Effectiveness and safety of procalcitonin evaluation for reducing mortality in adults with sepsis, severe sepsis or septic shock. Cochrane Database Syst Rev. 2017;1:CD010959.

20. Schuetz P, Wirz Y, Sager R, Christ-Crain M, Stolz D, Tamm M, Bouadma L, Luyt CE, Wolff M, Chastre J, et al. Procalcitonin to initiate or discontinue antibiotics in acute respiratory tract infections. Cochrane Database Syst Rev. 2017;10:CD007498

21. Schuetz P, Wirz Y, Sager R, Christ-Crain M, Stolz D, Tamm M, Bouadma L, Luyt CE, Wolff $M$, Chastre J, et al. Effect of procalcitonin-guided antibiotic treatment on mortality in acute respiratory infections: a patient level metaanalysis. Lancet Infect Dis. 2018;18(1):95-107.

22. Schuetz P, Briel M, Christ-Crain M, Wolbers M, Stolz D, Tamm M, Bucher H, Mueller B. Procalcitonin to initiate or withhold antibiotics in acute respiratory tract infections (protocol). Cochrane Database Syst Rev 2008; (Issue 4). Art. No.: CD007498.

23. Stewart LA, Clarke M, Rovers M, Riley RD, Simmonds M, Stewart G, Tierney JF, Group P-ID. Preferred reporting items for systematic review and metaanalyses of individual participant data: the PRISMA-IPD statement. JAMA. 2015;313(16):1657-65.

24. Liberati A, Altman DG, Tetzlaff J, Mulrow C, Gotzsche PC, loannidis JP, Clarke M, Devereaux PJ, Kleijnen J, Moher D. The PRISMA statement for reporting systematic reviews and meta-analyses of studies that evaluate health care interventions: explanation and elaboration. J Clin Epidemiol. 2009; 62(10):e1-34

25. Stolz D, Smyrnios N, Eggimann P, Pargger $H$, Thakkar N, Siegemund $M$ Marsch S, Azzola A, Rakic J, Mueller B, et al. Procalcitonin for reduced antibiotic exposure in ventilator-associated pneumonia: a randomised study. Eur Respir J. 2009;34(6):1364-75.

26. Shankar-Hari M, Phillips GS, Levy ML, Seymour CW, Liu VX, Deutschman CS, Angus DC, Rubenfeld GD, Singer M, Sepsis definitions task F. Developing a new definition and assessing new clinical criteria for septic shock: for the third international consensus definitions for sepsis and septic shock (Sepsis3). JAMA. 2016;315(8):775-87.

27. Guyatt GH, Oxman AD, Vist GE, Kunz R, Falck-Ytter Y, Alonso-Coello P, Schunemann HJ, Group GW. GRADE: an emerging consensus on rating quality of evidence and strength of recommendations. BMJ. 2008;336(7650):924-6.

28. Thompson SG, Turner RM, Warn DE. Multilevel models for meta-analysis, and their application to absolute risk differences. Stat Methods Med Res. 2001;10(6):375-92.

29. Turner RM, Omar RZ, Yang M, Goldstein H, Thompson SG. A multilevel model framework for meta-analysis of clinical trials with binary outcomes. Stat Med. 2000;19(24):3417-32.

30. Dellinger RP, Levy MM, Rhodes A, Annane D, Gerlach H, Opal SM, Sevransky JE, Sprung CL, Douglas IS, Jaeschke R, et al. Surviving Sepsis Campaign: international guidelines for management of severe sepsis and septic shock, 2012. Intensive Care Med. 2013;39(2):165-228.

31. Jun KR, Lee JN, Song SA, Oh SH, Lee JY, Shin JH, Kim HR. Serial changes in serum procalcitonin, interleukin 6, and C-reactive protein levels according to non-specific surgical stimulation. Clin Chemi Lab Med. 2015;53(4):549-58.
32. Henriquez-Camacho C, Losa J. Biomarkers for sepsis. Biomed Res Int. 2014; 2014:547818.

33. Schuetz P, Maurer P, Punjabi V, Desai A, Amin DN, Gluck E. Procalcitonin decrease over 72 hours in US critical care units predicts fatal outcome in sepsis patients. Crit Care. 2013;17(3):R115.

34. Schuetz P, Litke A, Albrich WC, Mueller B. Blood biomarkers for personalized treatment and patient management decisions in community-acquired pneumonia. Curr Opin Infect Dis. 2013:26(2):159-67.

35. Jones AE, Shapiro NI, Trzeciak S, Arnold RC, Claremont HA, Kline JA Emergency medicine shock research network I. Lactate clearance vs central venous oxygen saturation as goals of early sepsis therapy: a randomized clinical trial. JAMA. 2010;303(8):739-46.

36. Schuetz P, Mueller B. Procalcitonin: an effective screening tool and safe therapeutic decision making aid for emergency department patients with suspected sepsis. Ann Emerg Med. 2015;66(3):318-9.

37. Schuetz P, Mueller B. Biomarker-guided de-escalation of empirical therapy is associated with lower risk for adverse outcomes. Intensive Care Med. 2014; 40(1):141.

38. Schuetz P, Briel M, Christ-Crain M, Stolz D, Bouadma L, Wolff M, Luyt CE, Chastre J, Tubach F, Kristoffersen KB, et al. Procalcitonin to guide initiation and duration of antibiotic treatment in acute respiratory infections: an individual patient data meta-analysis. Clin Infect Dis. 2012;55(5):651-62.

39. FDA clears test to help manage antibiotic treatment for lower respiratory tract infections and sepsis. https://www.fda.gov/NewsEvents/Newsroom/ PressAnnouncements/ucm543160.htm. Accessed 15 Jan 2018.

40. Schuetz $P$, Wirz $Y$, Mueller B. Reassessment of a meta-analysis of procalcitonin-guided antibiotic therapy for lower respiratory tract infections—authors' reply. Lancet Infect Dis. 2018;18(2):141.

41. Jensen JU, Heslet $L$, Jensen $T H$, Espersen $K$, Steffensen P, Tvede M Procalcitonin increase in early identification of critically ill patients at high risk of mortality. Crit Care Med. 2006;34(10):2596-602.

42. Roberts RR, Hota B, Ahmad I, Scott RD 2nd, Foster SD, Abbasi F, Schabowski S, Kampe LM, Ciavarella GG, Supino M, et al. Hospital and societal costs of antimicrobial-resistant infections in a Chicago teaching hospital: implications for antibiotic stewardship. Clin Infect Dis. 2009;49(8):1175-84.

43. Classen DC, Jaser L, Budnitz DS. Adverse drug events among hospitalized Medicare patients: epidemiology and national estimates from a new approach to surveillance. Jt Comm J Qual Patient Saf. 2010;36(1):12-21.

44. Garnacho-Montero J, Gutierrez-Pizarraya A, Escoresca-Ortega A, CorciaPalomo Y, Fernandez-Delgado E, Herrera-Melero I, Ortiz-Leyba C, MarquezVacaro JA. De-escalation of empirical therapy is associated with lower mortality in patients with severe sepsis and septic shock. Intensive Care Med. 2014;40(1):32-40

45. Muller F, Christ-Crain M, Bregenzer T, Krause M, Zimmerli W, Mueller B, Schuetz P, Pro HSG. Procalcitonin levels predict bacteremia in patients with community-acquired pneumonia: a prospective cohort trial. Chest. 2010; 138(1):121-9.
Ready to submit your research? Choose BMC and benefit from:
- fast, convenient online submission
- thorough peer review by experienced researchers in your field
- rapid publication on acceptance
- support for research data, including large and complex data types
- gold Open Access which fosters wider collaboration and increased citations
- maximum visibility for your research: over $100 \mathrm{M}$ website views per year
At BMC, research is always in progress.
Learn more biomedcentral.com/submissions 